\title{
Influence of Curing Temperature on Shear Strength and Compressibility of Swelling Soil Stabilized with Hydrated Lime \\ DOI : 10.36909/jer.13889
}

\author{
${ }^{1}$ Nihad Bahaaldeen Salih, ${ }^{2 *}$ Tavga Aram Abdalla ${ }^{* *}$ \\ ${ }^{1}$ Assistant professor, Department of Water Resources Engineering, College of Engineering, University of Sulaimani, \\ Northern Iraq \\ ${ }^{2}$ Department of Civil Engineering, College of Engineering, University of Sulaimani, Northern Iraq \\ *Corresponding Author, E-mail: tavga.aram@gmail.com or tavga.abdalla@univsul.edu.iq \\ ORCID ID: https://orcid.org/0000-0002-6021-2633
}

\begin{abstract}
The exposed cohesive soils to temperature can face considerable physical and mechanical characteristics changes. Therefore, understanding the environmental events influences on the soil geotechnical properties is essential, which is significant in the rainy and cold places such as in Sulaimani city, northern Iraq. This experimental study examines the temperature changes $\left(10^{\circ} \mathrm{C}\right.$, and $50^{\circ} \mathrm{C}$ ) impacts on the durability of stabilized cohesive soil using $0 \%, 5 \%, 10 \%$ and $15 \%$ hydrated-lime added as a replacement on the soils dry mass. Consistency, unconfined compression, and compressibility characteristics were evaluated. Under the applied circumstances, a decrease was noticed in the magnitudes of liquid limit and plasticity index, while plastic limit generally increased within hydrated-lime percent increase. The study yielded an appreciable improvement of the cohesive soil's strength and compressibility properties with time progress, especially after the stabilization process is achieved.
\end{abstract}

Keywords: Cohesive Soil, Hydrated Lime, Temperature, Consistency, Strength, compressibility.

\section{INTRODUCTION}

In the last two decades, the impact of heating and cooling on clay soils as a technique of soil stabilization has been of considerable interest that has a major influence on many applications in engineering projects. Soil compressibility and permeability can be influenced by heating and cooling conditions (Qi et al., 2008). Lime has been used to enhance fine soils characteristics for a considerable time. Lime is useful in causing a modification in soils durability, shear strength, and 
plasticity (Al-Rawas et al., 2005; Guney et al., 2007; Dash and Hussain, 2012; Karkush and Abdulkareem, 2019; Abdalla and Salih, 2020). Physical and mechanical properties of expansive soil can improve by using industrial by-products such as lime, fly ash, Microbial Calcite, silica fume, natural pozzolana (Thyagaraj et al., 2012; Karkush et al., 2018; Noolu et al., 2018; Gadouri et al., 2019 AL-Ani et al., 2021). However, clayey soils plasticity instantaneously change (more or less) by using lime (Bagherpour and Choobbasti, 2003; Goswami and Singh, 2005; Ansary et al., 2006; Kavak and Akyarli, 2007; Manasseh and Olufemi, 2008). Then, several investigators (George et al. 1992; Rao and Shivananda 2005) concluded that there are still unclear problems with regard to soils-lime acceleration relationship after thermal curing. Hence, significant improvements in soil's elasticity modulus and strength were achieved by George et al. (1992); $50^{\circ} \mathrm{C}$ curing temperature was checked which performed to obtain any potential benefits of high temperature on soil-lime mixture. After that, compression $(\mathrm{Cc})$ and swelling $(\mathrm{Cr})$ indices were found to be negligible with temperature variations (Campanella and Mitchell, 1968). However, Cs (Abuel-Naga et al., 2007) and Cc (Tsutsumi and Tanaka, 2012) was changed with temperature. So, the $\mathrm{Cv}$ rate was increased as the temperature degree increased (Abuel-Naga et al., 2005). The variability of permeability with temperature causes that, as temperature rises, permeability rises (Abuel-Naga et al., 2005; Cui et al., 2009). Hightemperature $\left(5^{\circ} \mathrm{C}-70 \mathrm{o} \mathrm{C}\right)$ resulted in slight variation in compression and swelling indices (Jarad, 2016), which due to the dependency of these indices more on the applied pressure than temperature changes. The study's aim is to investigate the influences of curing temperature on the geotechnical characteristics of stabilized CL soil by hydrated lime. Potentially, the implementation of curing temperature variations on cohesive soil stabilized by hydrated lime modifies the soil behavior for various states of loading and saturation. 


\section{STUDY METHODOLOGY \\ MATERIAL USED \\ EXPANSIVE SOIL SAMPLE}

An intact soil sample categorized as low plasticity clay (CL) soil (USCS) was selected (see Figure 1, and Table 1), namely Barika soil, Sulaimani Governorate, northern Iraq (Latitude $=35.393755$ and Attitude = 45.595097). Some investigators (Rashed et al., 2017; Dong et al., 2019; Asad et al., 2019; Karkush and Yassin, 2020) recently used the soil site, which features clayey soils. The soil sample was collected from 1.0 to 2.0 meters depth from the natural ground level.

\section{USED HYDRATED-LIME}

The selected hydrated-lime (see Table 2) is locally-available, and specifically uses in building projects. It is obtained from Karbala Lime Factory, southern east of Iraq.

Table 1. The used cohesive sample engineering characteristics.

\begin{tabular}{ll}
\hline \multicolumn{1}{c}{ Property } & \multicolumn{1}{c}{ Value } \\
\hline Natural Moisture Content (\%) & 18.68 \\
Color & Light Brown \\
Silt + Clay (\%) & 70 \\
Liquid limit, L.L. (\%) & 44.63 \\
Plastic limit, P.L. (\%) & 19.46 \\
Plasticity index, P.I. & 25.17 \\
Specify gravity (Gs) & 2.67 \\
M.D.D. (gm/cm3) & 1.57 \\
O.M.C. (\%) & 27.25 \\
Soil Type (USCS) & CL \\
\hline
\end{tabular}

Table 2. Some engineering characteristics for the used hydrated-lime.

\begin{tabular}{ll}
\hline Mineral Type & $(\%)$ \\
\hline $\mathrm{CaO}$ & 56.1 \\
$\mathrm{MgO}$ & 0.13 \\
$\mathrm{Fe}_{2} \mathrm{O}_{3}$ & 0.12 \\
$\mathrm{Al}_{2} \mathrm{O}_{3}$ & 0.72 \\
$\mathrm{SiO}_{2}$ & 1.38 \\
$\mathrm{SO}_{3}$ & 0.21 \\
$\mathrm{~L} . \mathrm{O} . \mathrm{I}$ & 40.6 \\
\cline { 2 - 2 } & Physical Properties \\
\cline { 2 - 2 } Passing sieve No.200 $(\%)$ & 98 \\
Surface Area $\left(\mathrm{m}^{2} / \mathrm{kg}\right)$ & 398 \\
Specific Gravity $\left(\mathrm{G}_{\mathrm{s}}\right)$ & 2.78 \\
\hline
\end{tabular}




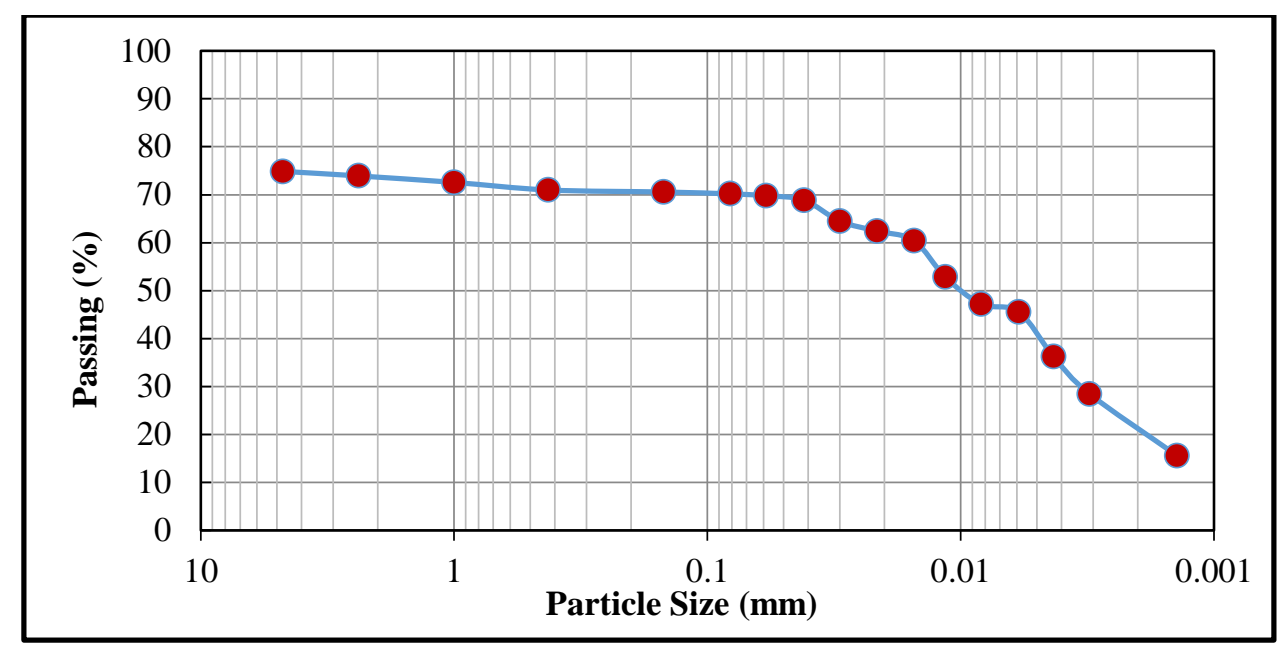

Figure 1. Drawn curve of cohesive soil sample particle-size.

\section{METHOD OF TESTING}

\section{ATTERBERG LIMITS TESTS}

Liquid and plastic limits and plasticity index were determined by using ASTM D4318 (2000). Plasticity index (PI) Variations were then studied before and after using hydrated-lime (0\%, 5\%, $10 \%$, and 15\%). Therefore, the air-dried soil sample was sieved (No. 40), and the required hydrated-lime percentages were prepared and mixed thoroughly with the soil sample. De-ionized water was used for the soil-lime mixture preparation, which left in order to mature for 24 hours in an airtight container.

\section{MECHANICAL INDICES}

The unconfined compressive strength (UCS) samples (38 mm diameter, and $83 \mathrm{~mm}$ height) were tested (ASTM D2166, 2000) by using a $0.5 \mathrm{~mm} / \mathrm{min}$ extension rate, which continued until the sample failure. In addition, the 1-D consolidation test (50 mm diameter, and $20 \mathrm{~mm}$ thickness) was conducted according to ASTM D 2435 (2011). For assessing the influence of curing temperature on the strength and compressibility components, the prepared samples were arranged at $25^{\circ} \mathrm{C}-27^{\circ} \mathrm{C}$ and kept in sealed containers, then cured into various durations $(0,7,14$, $\& 28$ days). The curing process was performed for $10^{\circ} \mathrm{C}$ and $50{ }^{\circ} \mathrm{C}$. 


\section{SAMPLES PREPARATION AND TESTING PROCEDURCE}

- Preparing a clean steel mold (38 $\mathrm{mm}$ diameter and $83 \mathrm{~mm}$ height) to prepare the untreated and treated soil sample for UCS determination that was experimented at an axial strain of 0.5 $\mathrm{mm} / \mathrm{min}$.

- Utilization of a ring of $50 \mathrm{~mm}$ thickness and $20 \mathrm{~mm}$ diameter for the conduction of 1-D consolidation test for the intact and treated soil samples.

- For the treated samples, the hydrated lime is added at a percentage of $0 \%, 5 \%, 10 \%$, and $15 \%$ as a replacement from the dry mass of the intact soil sample.

- To determine the effect of curing temperature on the strength and compressibility parameters of the treated soil, three samples were prepared for each added percent of hydrated lime at room temperature $\left(25^{\circ} \mathrm{C}-27^{\circ} \mathrm{C}\right)$.

- The test samples were cured at temperatures of $10^{\circ} \mathrm{C}$, and $50^{\circ} \mathrm{C}$ by leaving them in sealed containers for curing $(0,7,14$, and 28 days) before testing.

- For each hydrated lime content and curing period, three identical samples were tested and the average value was considered.

- Finally, all the prepared soil samples after being subjected to the curing temperatures were tested for determination of the UCS and 1-D consolidation parameters.

\section{OBTAINED RESULTS AND THEIR DISCUSSIONS \\ ATTERBERG LIMITS}

Each relationship of the presented Atterberg limits of the treated samples (see Figure 2) showed a different response to the carried out soil treatment. It is clear that, with hydrated-lime percent increase (0\% to $15 \%)$, liquid limit (LL) and PI values were reduced $(-19.34 \%$ and $-88.04 \%$ respectively). However, the plastic limit (PL) value tends to rise, 69.52\% variation was obtained. Overall, increase the hydrated-lime content has resulted in plasticity characteristics reduction, similar to the findings of Ansary et al. (2006); Amu et al. (2011); Khattab and Aljobouri (2011); 
Dash and Hussain (2012); Gharib et al. (2012); Mohammed and Elsharief (2015). The occurrence of cation exchange as a consequence of some ions' interchange with hydrated-lime may cause an instant variation in the material workability, which can happen inside the clay structure. Therefore, the PL increased and the PI decreased (Thyagaraj and Zodinsanga, 2014; Jha and Sivapullaiah, 2015). The plasticity changes take place more over time, due to the influence of pozzolan reactions that start to affect so that PI continues to decrease. This plasticity reduction gives a further brittle texture for the soil-lime mixtures, rendering the soil more vulnerable to field equipment movement and manipulation.

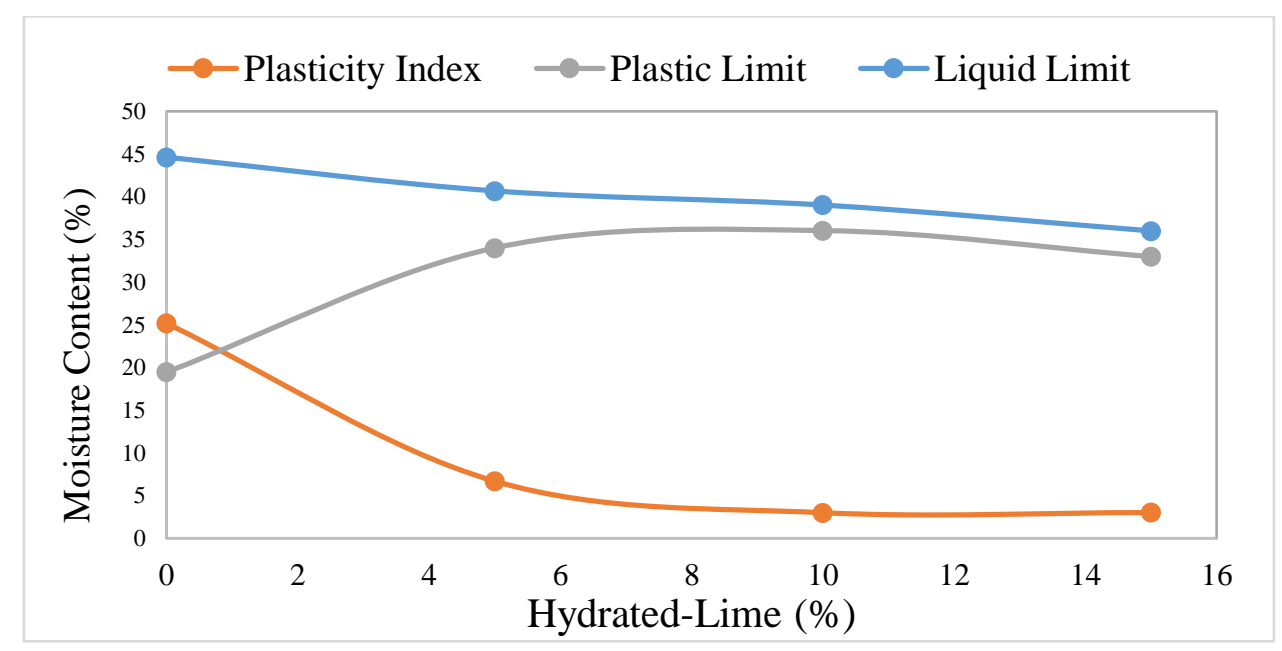

Figure 2. Variation of Atterberg limits and plasticity index with hydrated-lime percent increase.

\section{UNCONFINED COMPRESSION TEST}

At elevated curing temperature (hydrated-lime percent increase), samples strength significantly rises (Figures 3 and 4). The gained strength due to the hydrated-lime content increase is marginal for the cured samples by $10^{\circ} \mathrm{C}$. The addition of hydrated-lime $(0 \%$ to $15 \%)$ caused the UCS to be increased $(269.41 \mathrm{kPa}$ to $616.6 \mathrm{kPa})$ when cured at $10^{\circ} \mathrm{C}$ for 28 days. However, a significant improvement in the strength of the samples (386.21 kPa to $2514.98 \mathrm{kPa})$ was obtained within 28 days of curing at $50^{\circ} \mathrm{C}$, which happened when the hydrated-lime content increased from $5 \%$ to $15 \%$. 
Higher strength was achieved as a comparison between applications of $50^{\circ} \mathrm{C}$ and $10^{\circ} \mathrm{C}$. This shows that not only does the hydrated-lime content cause modification; a major role also can be achieved in accelerating the mixture of hydrated-lime and soil reactions. The results clearly show that curing time and temperature for $0 \%$ hydrated-lime percent treated samples are not very successful in gaining strength. In comparison, at $15 \%$ hydrated-lime content cured by $50^{\circ} \mathrm{C}$, the highest strength rate increase was obtained. Importantly, it is clear that the 7 day curing period is essential to gain higher strength regardless of the hydrated-lime content and temperature degree for curing. In addition, the strength gain rate decreased gradually due to the curing period increased. This depends on the hydrated-lime quality and curing temperature degree. Similarly, UCS modification for stabilized soils by lime was obtained by (Osinubi and Nwaiwu (2006); Amadi and Okeiyi (2017).

The cation interchange, which is a physicochemical phenomenon that happens between clay particles and hydrated lime in addition to the process of flocculation-agglomeration, can be because of shear strength enhancement of the stabilized soil by hydrated-lime. Instant changes in the stabilized soil properties will take place quickly due to the mentioned actions. Moreover, among silica, alumina, and calcium ions, pozzolanic reactions after that will happen for the samples of clay minerals. The obtained results are similar to the results of Alzubaidi and Lafta (2013); Zhao et al (2014); Jha and Sivapullaiah (2015) for the production of cement products for strength increase. 


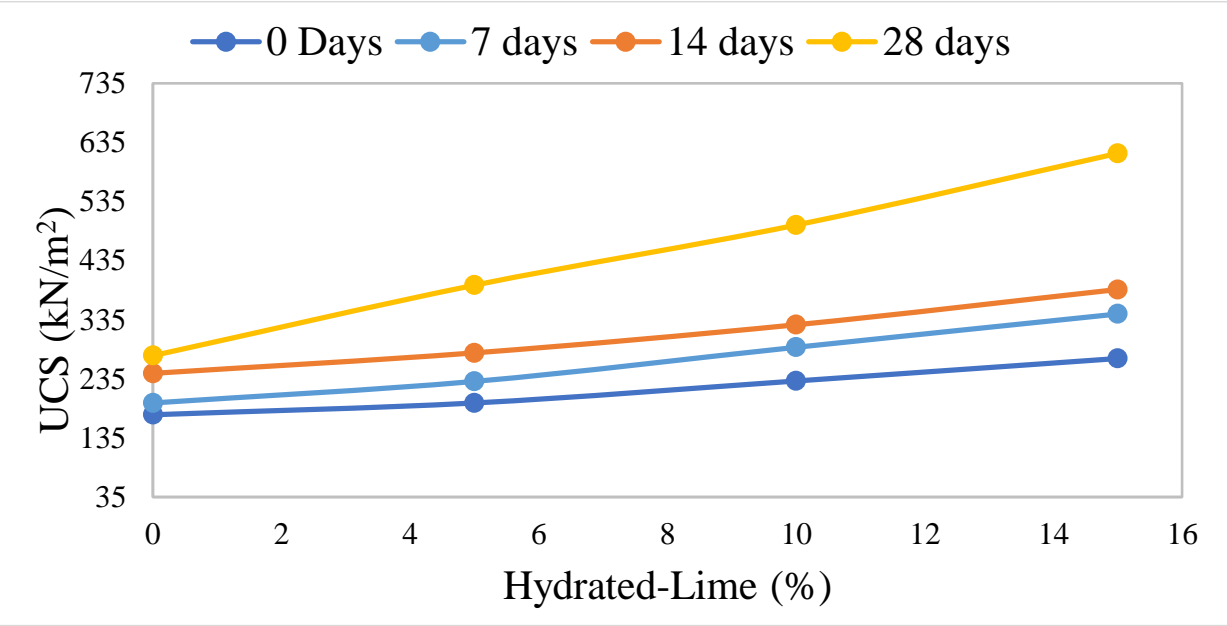

Figure 3. Hydrated-lime and curing period (at $10^{\circ} \mathrm{C}$ ) impacts on unconfined compressive strength.

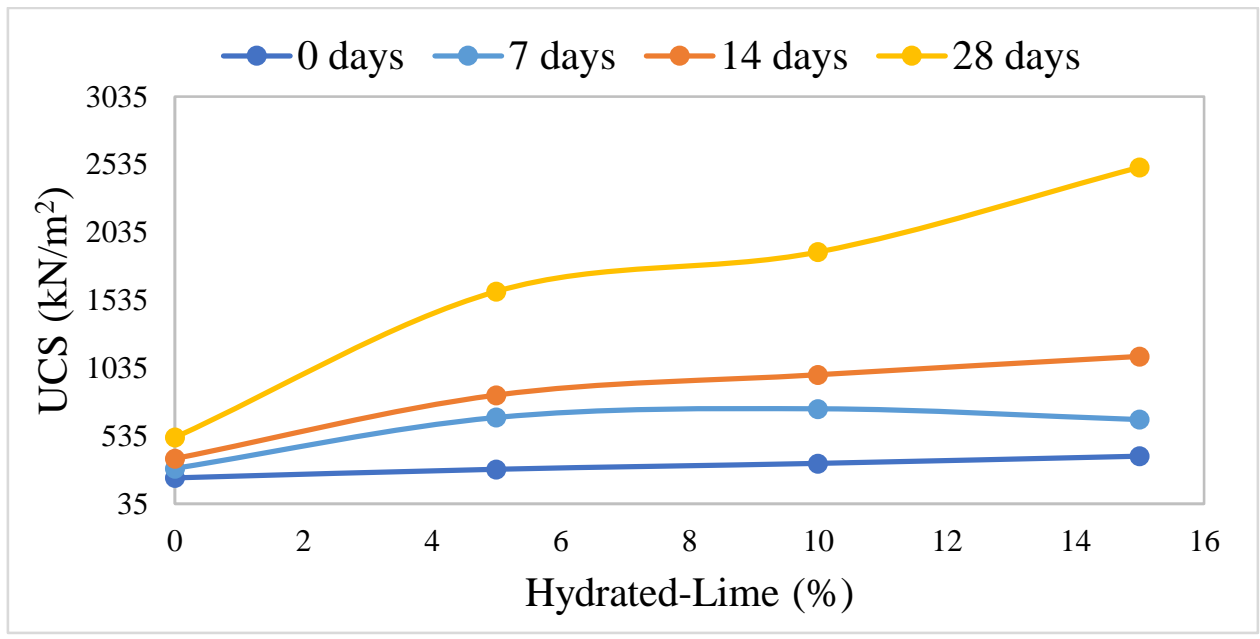

Figure 4. Hydrated-lime and curing period impacts (at $50^{\circ} \mathrm{C}$ ) on unconfined compressive strength.

\section{ONE-DIMENSIONAL CONSOLIDATION}

The compressibility characteristics of CL soil samples with various hydrated-lime percent and different curing temperatures at $10^{\circ} \mathrm{C}$ and $50^{\circ} \mathrm{C}$ after $0,7,14$, and 28 days have been studied. The compression index $(\mathrm{Cc})$ and swelling index $(\mathrm{Cr})$ were decreased due to curing temperature increase (Figures 5 and 6). The addition of $15 \%$ hydrated-lime cured for 28 days at $10^{\circ} \mathrm{C}$ resulted in $\mathrm{C}_{\mathrm{c}}$ and $\mathrm{C}_{\mathrm{r}}$ decrease from 0.1204 to 0.0294 and 0.017 to 0.005 respectively. However, the improvement in compressibility characteristics can be noticed after the samples are cured at 
$50^{\circ} \mathrm{C} . \mathrm{C}_{\mathrm{c}}$ and $\mathrm{C}_{\mathrm{r}}$ changes (see Figures 7 and 8) are $0.1042-0.0112$ and $0.012847-0.00567$ respectively due to $15 \%$ hydrated-lime and 28 days curing.

Lower compressibility was achieved for stabilized soil samples by hydrated-lime cured at $50^{\circ} \mathrm{C}$ compare to similar stabilized samples cured at $10^{\circ} \mathrm{C}$. This achieved outcome shows that the hydrated-lime is not only the factor that has modified the compressibility parameters, the curing temperature and time also caused notable modifications in the values of $\mathrm{C}_{\mathrm{c}}$ and $\mathrm{C}_{\mathrm{r}}$. The thermal curing process therefore importantly caused reductions in the stabilized samples $C_{c}$ and $C_{r}$. Similarly, the role of temperature to decrease soil's compressibility properties was proven in some studies such as Marques et al. (2004); Tang et al. (2007); Tsutsumi and Tanaka (2012).

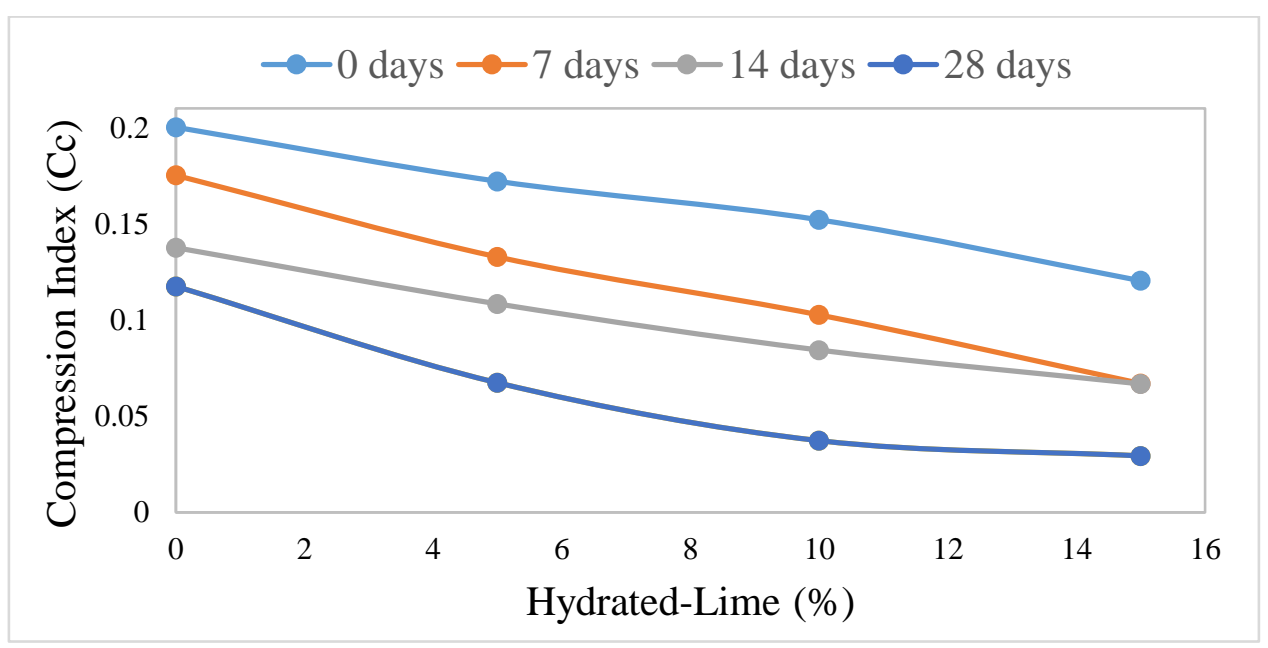

Figure 5. Hydrated-lime and curing time $\left(\right.$ at $\left.10^{\circ} \mathrm{C}\right)$ impacts on compression index. 


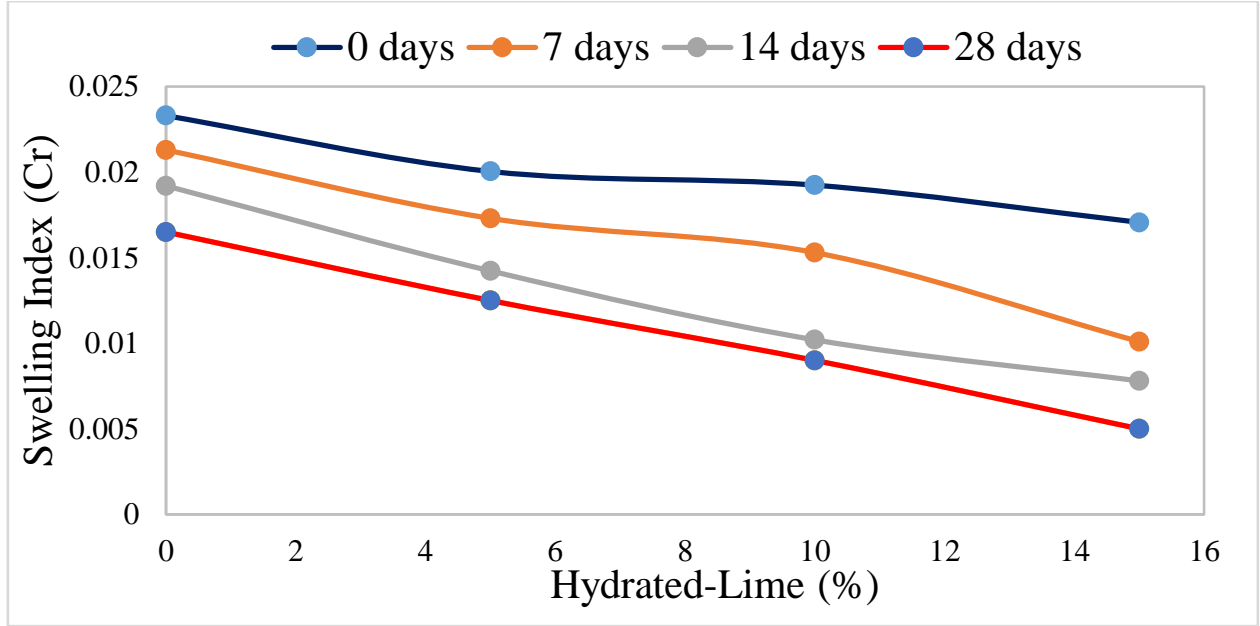

Figure 6. Hydrated-lime and curing period (at $10^{\circ} \mathrm{C}$ ) impacts on swelling index.

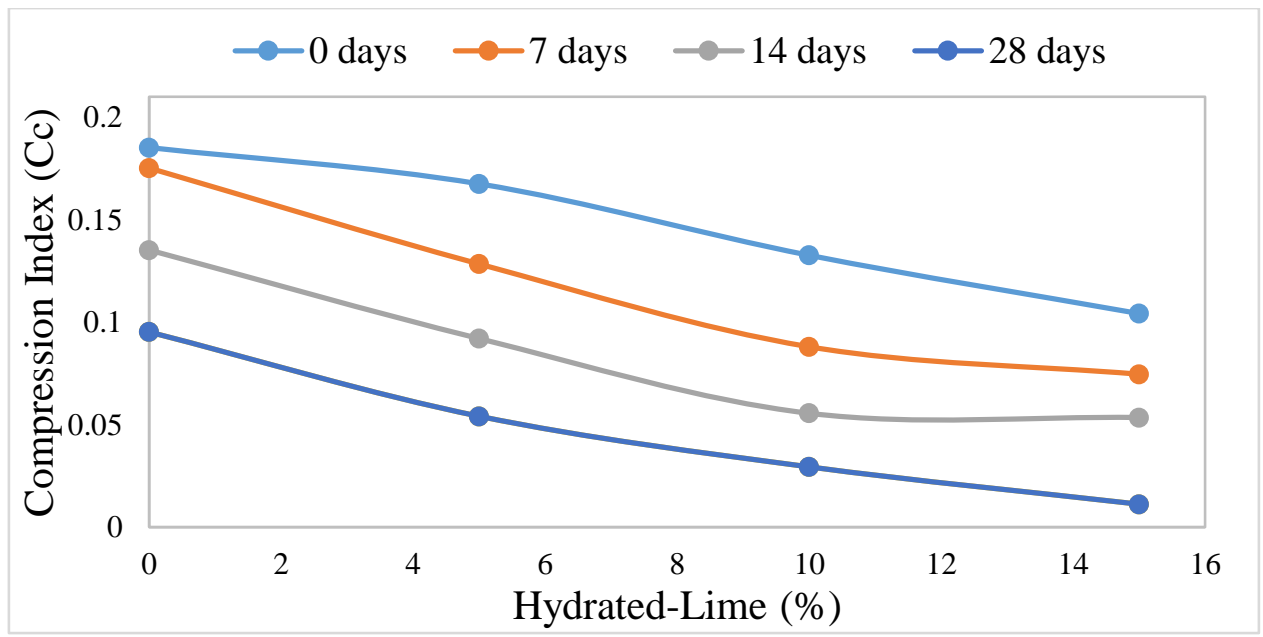

Figure 7. Hydrated-lime and curing period (at $50^{\circ} \mathrm{C}$ ) impacts on compression index.

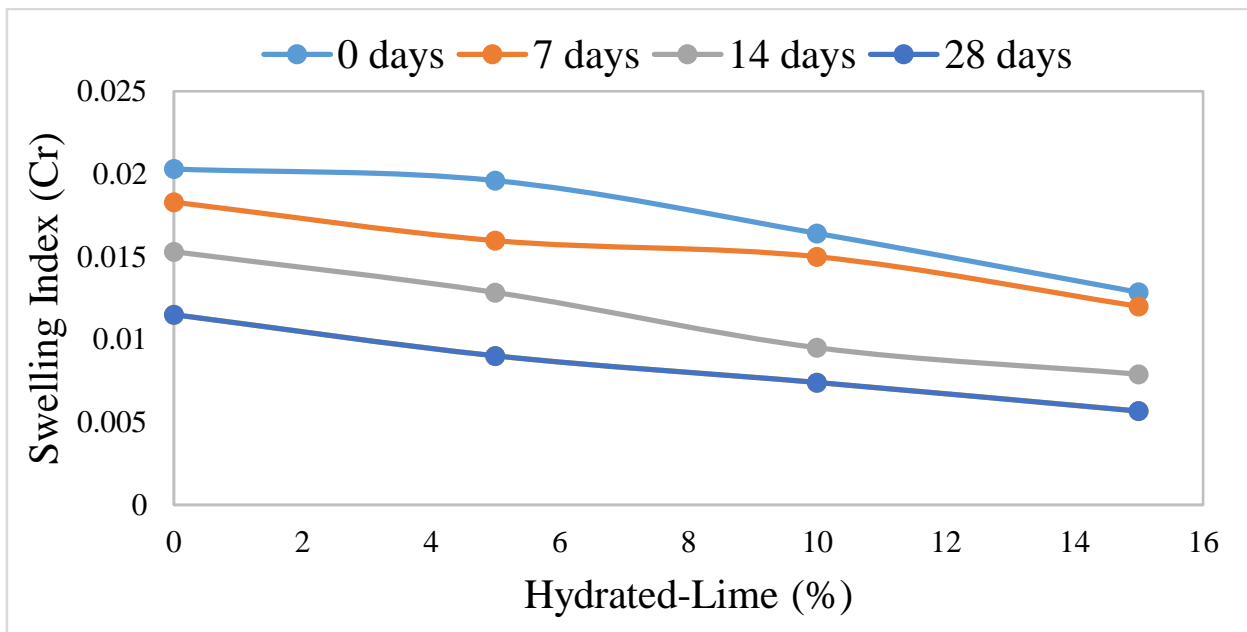

Figure 8. Hydrated-lime and curing time (at $50^{\circ} \mathrm{C}$ ) on swelling index. 


\section{Conclusions}

Considering the achieved results from the extensive experimental testing program, the outcomes yielded in the following conclusions:

- Utilization of hydrated-lime with curing temperature increase importantly decrease consistency parameters, plasticity index, and liquid limit.

- Hydrated-lime significantly increased unconfined compressive strength, which is very susceptible to curing temperature; highest strength was gained after 28 days curing at $50^{\circ} \mathrm{C}$.

- The addition of hydrated lime resulted in an appreciable effect on decreasing $\mathrm{Cc}$ and $\mathrm{Cr}$ at different curing temperatures and times, especially due to $15 \%$ hydrated lime, and $50^{\circ} \mathrm{C}$ for 28 days curing time.

\section{REFERENCES}

Abdalla, T. A. and Salih, N. B. 2020. Hydrated Lime Effects on Geotechnical Properties of Clayey Soil. Journal of Engineering 26 (11):150-169.

Abuel-Naga, H. M., Bergado, D. T., Bouazza, A., Ramana, G. V. 2007. Volume change behavior of saturated clays under drained heating conditions: experimental results and constitutive modeling. Canadian Geotechnical Journal 44: 942-956.

Abuel-Naga, H. M., Bergado, D. T., Soralump, S., Rujivipat, P.2005. Thermal consolidation of soft Bangkok clay. Lowland Technology International 7: 13-21.

AL-Ani, S.M., Karkush, M.O., Zhussupbekov, A. and Al-Hity, A.A. 2021. Influence of Magnetized Water on the Geotechnical Properties of Expansive Soil. In Modern Applications of Geotechnical Engineering and Construction (pp. 39-50). Springer, Singapore.

Al-Rawas, A. A., Hago, A. W., and Al-Sarmi H. 2005. Effect of Lime, Cement and Sarooj (Artificial Pozzolan) on the Swelling Potential of an Expansive Soil from Oman. Build Environ 40: 681-687. 
Alzubaidi, R., Lafta, S. 2013. Effect of strain rate on the strength characteristics of soil-lime mixture. Geotech Geol Eng.

Amadi, A. A. and Okeiyi, A.2017. Use of quick and hydrated lime in stabilization of lateritic soil: comparative analysis of laboratory data. Geo-Engineering 8 (3): 1-13.

Amu, O. O., Bamisaye, O. F., and Komolafe, I. A. 2011. The suitability and lime stabilization requirement of some lateritic soil Samples as pavement. International Journal of Pure and Applied Sciences and Technology 2 (1): 29-46.

Ansary, M.A., Noor, M.A., and Islam, M. 2006. Effect of fly ash stabilization on geotechnical properties of Chittagong coastal soil." Soil Stress-Strain Behavior: Measurements, Modeling and Analysis Geotechnical Symposium in Roma, March 16 \& 17: 443-454.

Asad, A., Hussain, A., Farhan, A., Bhatti, A. A., and Munir, M. 2019. Influence of lime on low plastic clay soil used as subgrade. J. Mech. Cont. \& Math. Sci 14 (1): 69-77.

ASTM, D2166.2000. Standard Test Methods for Unconfined Compressive Strength of Cohesive Soil. ASTM International, West Conshohocken, PA, USA.

ASTM, D2435 .2011. Standard Test Methods for One - Dimensional Consolidation Properties of Soils Using Incremental Loading. ASTM International, West Conshohocken, PA, USA.

ASTM, D4318 .2000. Standard Test Methods for Liquid Limit, Plastic Limit, and Plasticity Index of Soils. ASTM International, West Conshohocken, PA, USA.

Bagherpour, I. and Choobbasti, A. J. 2003. Stabilization of fine grained soils by adding micro Silica and Lime or Micro Silica and Cement. Electron J. Geotech Eng 8: 1-10.

Campanella, R. G., Mitchell, J. K. 1968. Influence of temperature variations on soil behavior. ASCE 94: 709-734.

Cui, Y., Le, T. T., Tang, A. M., Delage, P., and Li, X. L. 2009. Investigating the Time Dependent Behavior of Boom Clay under Thermo-Mechanical Loading. Géotechnique 59:319-329. 
Dash, S. K. and Hussain, M. 2012. Lime stabilization of soils. Journal of Materials in Civil Engineering, ASCE 24 (6):707-714.

Dong, J. G., Xu, G. Y., Lv, H. B., \& Yang, J. Y. 2019. Development of instrument for wettingdrying cycles of expansive soil under simulated loads and experimental research. Journal of Engineering Research 7(3): 1-12

Gadouri, H., Harichane, K., \& Ghrici, M. 2019. Effect of the interaction between calcium sulphate and mineral additives on shear strength parameters of clayey soils. Journal of Engineering Research 7(2): 66-88.

George, S. Z., Ponniah, D. A., and Little, J. A. 1992. Effect of temperature on lime-soil stabilization. Construction and Building Materials 6 (4):247-252.

Gharib, M., Saba, H. and Barazesh, A. 2012. Experimental Investigation of Impact of Adding Lime on Atterberg Limits in Golestan Province Soils. Journal of Applied and Basic Sciences, ECISI 3 (4):796 - 800.

Goswami, R. K. and Singh, B. 2005. Influence of fly ash and lime on plasticity characteristics of residual lateritic soil. Ground Improvement 9: 175-182.

Guney, Y., Sari, D., Cetin, M., and Tuncan, M. 2007. Impact of Cyclic Wetting-Drying on Swelling Behaviour of Lime-Stabilized Soil. Build Environ 42: 681-688.

Jarad .2016. Temperature impact on the consolidation and creep behaviour of compacted clayey soils. PhD thesis. Mechanics of materials [physics. class-ph]. Université de Lorraine, France.

Karkush, M.O. and Abdulkareem, M.S. 2019. Deep remediation and improvement of soil contaminated with residues oil using lime piles. International Journal of Environmental Science and Technology 16(11): 7197-7206.

Karkush, M.O. and Yassin, S.2020. Using sustainable material in improvement the geotechnical properties of soft clayey soil. Journal of Engineering Science and Technology 15(4): 2208-2222. 
Karkush, M.O., Ali, H.A. and Ahmed, B.A. 2018. Improvement of Unconfined Compressive Strength of Soft Clay by Grouting Gel and Silica Fume. In Proceedings of China-Europe Conference on Geotechnical Engineering (pp. 546-550). Springer, Cham.

Kavak, A. and Akyarli, A. 2007. A Field Application for Lime Stabilization. Env Geol 51: 987-997.

Khattab, S. I. and Khalaf, M. M. 2011. Effect of Combined Stabilization by Lime and Cement on Hydraulic Properties of Clayey Soil Selected From Mosul Area. Al-Rafidain Engineering $20(6): 139-153$.

Manasseh, J. and Olufemi, A. I. 2008. Effect of Lime on some Geotechnical Properties of Igumale Shale. Electron J Geotech Eng 13:1-12.

Marques, M. E., Leroueil, S., and Almeida, M. S. 2004. Viscous Behaviour of St Roch-de1'Achigan Clay, Can. Geotech. J. 41: 25-38.

Mohammed, A. A. and Alsharief, A. M. 2015. Engineering Properties of Lime Stabilized Swelling Soils from Sudan. International Journal of Science, Engineering and Technology Research (IJSETR) 4 (10): 3595-3600.

Noolu, V., \& Pillai, R. J. 2018. Multi-scale laboratory investigation on black cotton soils stabilized with calcium carbide residue and fly ash. Journal of Engineering Research 6(4): 1-15.

Osinubi, K. J. and Nwaiwu, M. O. 2006. Compaction Delay Effects on Properties of LimeTreated Soil. J Mater Civil Engineering 18 (2):250-258.

Qi, J., Ma, W., and Song, C. 2008. Influence of Freeze-Thaw on Engineering Properties of a silty soil. Cold Regions Science and Technology 53 (3):397-404.

Rao, S. M. and Shivananda, P. 2005. Compressibility Behaviour of Lime-Stabilized Clay. Geotechnical and Geological Engineering 23: 309-319.

Rashed, K. A., Salih, N. B., and Abdalla, T. A. 2017. Correlation of Consistency and Compressibility Properties of Soils in Sulaimani City. Sulaimani Journal for Engineering Sciences 4 (5): 87-95. 
Tang, A. M., Cui, Y. J., and Barnel, N. 2007. A New Isotropic Cell for Studying the ThermoMechanical Behavior of Unsaturated Expansive Clays. Geotechnical Testing Journal 30: 341 348.

Tsutsumia A.,n , Tanaka H. 2012. Combined effects of strain rate and temperature on consolidation behavior of clayey soils. Soils and Foundations 52(2): 207-2015

Villar, M. V., Gómez-Espina, R., and Lloret, A. 2010. Experimental Investigation into Temperature Effect on Hydro-Mechanical Behaviours of Bentonite. Journal of Rock Mechanics and Geotechnical Engineering 2: 171-78.

Zhao, H., Liu, J., Guo, J., Zhao, C., and Gong, B. 2014. Reexamination of Lime Stabilization Mechanisms of Expansive Clay. J Mater Civil Engineering 7. doi:10.1061/(ASCE)MT.19435533.0001040. 